\title{
Technical note: Rapid method for determination of amino acids in milk
}

\author{
R. Marino, ${ }^{* 1}$ M. lammarino,† A. Santillo, ${ }^{*}$ M. Muscarella, $†$ M. Caroprese, ${ }^{*}$ and M. Albenzio* \\ *Department of Production and Innovation in Mediterranean Agriculture and Food System (PrIME) University of Foggia, Via Napoli, \\ 25-71100 Foggia, Italy \\ †Istituto Zooprofilattico Sperimentale della Puglia e della Basilicata, Via Manfredonia, 20-71100 Foggia, Italy
}

\section{ABSTRACT}

A rapid method for measurement of amino acids in milk was developed and validated. The method included a first step of milk protein hydrolysis, followed by the derivatization and separation of amino acids by HPLC. Six combinations of hydrolysis agent and temperature-time conditions were compared with a reference method; derivatization procedures as well as HPLC separation were improved. Hydrolysis of milk samples with $6 \mathrm{~N} \mathrm{HCl}$ at $160^{\circ} \mathrm{C}$ for 60 min resulted in no significantly differences compared with the reference method but allowed the analysis of a greater number of milk samples in a short time. In addition, this method was characterized by high precision, low repeatability uncertainty, and high accuracy for all amino acids evaluated; the recovery mean value of the single amino acids was $98.38 \%$. The proposed method is, therefore, accurate, simple, rapid, and suitable for large numbers of milk samples.

Key words: amino acid, HPLC, derivatization, milk

Determination of the amino acid profile in milk is essential for qualitative evaluation of peptides and proteins that can affect the chemical and nutritional properties of milk. The measurement of amino acid composition is a complex analytical process, consisting of 2 steps: 1) hydrolysis of substrate; and 2) derivatization and chromatographic analyses. As reported by Fountoulakis and Lahm (1998), hydrolysis is a critical step for this analysis, being the main source of analytical errors. The official reference procedure is a liquid-phase hydrolysis performed in constantly boiling $6 \mathrm{~N} \mathrm{HCl}$ under vacuum at $110^{\circ} \mathrm{C}$ for $24 \mathrm{~h}$ (AOAC, 1994). The long time required for hydrolysis could be a limitation of the official method. Amino acids are derivatized before analysis, which could also represent a critical step of the protocol. In particular, the choice of an optimal combination of sample, buffer, and fluorescence agents is necessary

Received December 18, 2009.

Accepted February 24, 2010.

${ }^{1}$ Corresponding author: r.marino@unifg.it to obtain an adequate final $\mathrm{pH}$ value to improve the derivatization efficiency. Although a reference method is reported for amino acid analysis in food products, no studies have been carried out on the determination of AA in milk as a specific food substrate. The objective of this technical note is to provide a method for the determination of AA in milk. For this purpose, 6 combinations of hydrolysis agent and analysis conditions were compared with the reference procedure. For all proposed methods, the derivatization reaction and HPLC chromatographic separations was performed according to Henderson et al. (2000), with modification.

Individual milk samples (at least $200 \mathrm{~mL}$ ) were collected from 12 cows; total protein content was determined using an infrared spectrophotometer (MilkoScan 133B, Foss Electric, Hillerød, Denmark; IDF, 1990) and was $3.35 \% \pm 0.35$ SEM. A pretrial was conducted combining hydrolysis agent $[\mathrm{HCl}$ and methanesulfonic acid (MSA)], time of analysis (from $24 \mathrm{~h}$ to $45 \mathrm{~min}$ ), and temperature (from 110 to $160^{\circ} \mathrm{C}$ ). All analytical methods were compared with the reference hydrolysis method $\left(6 \mathrm{~N} \mathrm{HCl}\right.$ at $110^{\circ} \mathrm{C}$ for $24 \mathrm{~h}$ ), and 6 methods were chosen on the basis of a total AA recovery $>70 \%$ compared with the reference method. The 6 selected methods are showed in Table 1. Each hydrolysis method was repeated 3 times for each of the 12 cow milk samples. The hydrolysis of milk proteins was performed in Pyrex microcapillary tubes (Pierce Chemical Company, Rockford, IL) under vacuum and heated at the temperatures reported in Table 1 using a conventional oven. The same volumes of milk (250 $\mu \mathrm{L})$ and hydrolysis agent $(250 \mu \mathrm{L})$ were used for each method,. After hydrolysis, the tubes were cooled and the samples were filtered using Spartan-HPLC 13-mm syringe filters $(0.45 \mu \mathrm{m}, 30 \mathrm{~mm}$; Schleicher and Schuell, Dassel, Germany); the filtrate was diluted with distilled water $(1: 20 \mathrm{vol} / \mathrm{vol})$ in amber glass vials.

Amino acids were determined by HPLC. Before injection, AA were derivatized on-line using o-phthaldehyde (OPA) for primary AA and 9-fluorenylmethyl chloroformate (FMOC) for secondary AA according to the method of Henderson et al. (2000), modified to optimize the parameters for milk analysis. The following 
Table 1. Combinations of hydrolysis agent and conditions (time and temperature) tested

\begin{tabular}{llcr}
\hline & & \multicolumn{2}{c}{ Hydrolysis conditions } \\
\cline { 3 - 4 } Method & Hydrolysis agent & Temperature $\left({ }^{\circ} \mathrm{C}\right)$ & Time \\
\hline Ref. $^{1}$ & Hydrochloric acid $6 N$ & 110 & $24 \mathrm{~h}$ \\
A & Methanesulfonic acid $4 N$ & 110 & $24 \mathrm{~h}$ \\
B & Methanesulfonic acid 4 & 150 & $90 \mathrm{~min}$ \\
$\mathrm{C}$ & Hydrochloric acid 6 & 160 & $120 \mathrm{~min}$ \\
$\mathrm{D}$ & Hydrochloric acid 6 $N$ & 160 & $105 \mathrm{~min}$ \\
$\mathrm{E}$ & Methanesulfonic acid $4 \mathrm{~N}$ & 160 & $45 \mathrm{~min}$ \\
$\mathrm{~F}$ & Hydrochloric acid 6 & 160 & $60 \mathrm{~min}$ \\
\hline
\end{tabular}

${ }^{1}$ Ref $=$ reference method (AOAC, 1994).

volumes were injected: $26 \mu \mathrm{L}$ of borate buffer mixed with $0.1 \mu \mathrm{L}$ of sample, $0.3 \mu \mathrm{L}$ of OPA, $0.3 \mu \mathrm{L}$ of FMOC reagent, and $16 \mu \mathrm{L}$ of HPLC-grade water. The HPLC system (1100 series, Agilent Technologies, Waldbronn, Germany) was composed of a binary pump equipped with micro vacuum degasser, thermostat-controlled autosampler, column compartment, a fluorescence detector (model G1321A), and a diode array detector (model G1315A). The analyses were performed using a Zorbax Eclipse AAA column $(150 \times 4.6 \mathrm{~mm}$ i.d., prepacked with $3.5 \mu \mathrm{m}$ particles; Palo Alto, CA); the column temperature was set at $40^{\circ} \mathrm{C}$. The mobile phase comprised a $40 \mathrm{mM} \mathrm{NaH} \mathrm{PO}_{4} \cdot \mathrm{H}_{2} \mathrm{O}$ solution (phase A) and a mixture of water, methanol, and acetonitrile (10:45:45 vol/vol/vol; phase B). The elution of samples was performed at a flow rate of $2.0 \mathrm{~mL} / \mathrm{min}$ by gradient elution, and the total run time was $30 \mathrm{~min}$. Fluorescence detection was carried out at 340 (excitation) and $450 \mathrm{~nm}$ (emission). The UV diode array detector was used to determine cystine at $338 \mathrm{~nm}$. Individual amino acid peaks were identified by comparing their retention times with those of standards (Sigma-Aldrich, St. Louis, MO). Nine hundred microliters of standard mix solution of 17 AA (Asp, Glu, Ser, His, Gly, Thr, Arg, Ala, Tyr, Cys, Val, Met, Phe, Ile, Leu, Lys, and Pro) at a concentration of $1 \mathrm{nmol} / \mu \mathrm{L}$ and $100 \mu \mathrm{L}$ of Asn, Gln, and Trp at $9 \mathrm{nmol} / \mu \mathrm{L}$ were mixed in a vial to obtain standard solutions with a concentration of $900 \mathrm{pmol} /$ $\mu \mathrm{L}$ for each amino acid.

Results are reported as milligrams of amino acid per gram of total AA. For each single amino acid, precision (CV \%), recovery, repeatability uncertainty, linearity, limit of determination (LOD), and limit of quantification (LOQ) were evaluated. Total recovered AA were determined as the sum of each amino acid on the protein content, as reported by Davis et al. (1994). Recovery percentage of each amino acid was evaluated by adding $1 \mathrm{~g}$ of lysozyme lyophilized powder (Sigma-Aldrich) to an aliquot of milk sample. The amount of AA detected in the sample with added lysozyme minus the amount of AA detected in a sample without lysozyme gave the percentage recovery of each amino acid (Tristam, 1953). Repeatability uncertainty was studied on 6 analyses of the same sample. The standard solution was diluted with $0.1 \mathrm{~N} \mathrm{HCl}$ to obtain the following concentrations: 450,225 , and $112.5 \mathrm{pmol} / \mu \mathrm{L}$; linearity of the analysis was determined from 112.5 to $900 \mathrm{pmol} / \mu \mathrm{L}$ of standard solution by plotting peak response (area of the amino acid peak divided by the area of the internal standard peak) against concentration. The LOD and LOQ were calculated according to the following equations (Miller and Miller, 1993):

$$
\begin{aligned}
& \mathrm{LOD}=3.3 \mathrm{~s} \mathrm{a} / \mathrm{b} \\
& \mathrm{LOQ}=10 \mathrm{~s}_{\mathrm{a}} / \mathrm{b},
\end{aligned}
$$

where $s_{a}$ is the standard deviation of the intercept and $\mathrm{b}$ is the slope of the regression line, obtained from the calibration curve. The repeatability uncertainty was calculated according to Hund et al. (2001).

The effect of the proposed methods and the reference method on amino acid levels and recovery percentages was analyzed using the GLM procedure of the SAS software package (SAS Institute Inc., Cary, NC). When significant effects were found (at $P<0.05$ unless otherwise noted), Student's $t$-test was used to locate significant differences between means.

Table 2 shows the AA content of cow milk samples determined using the 6 different hydrolysis methods and the reference method. The concentration of each amino acid was significantly affected by hydrolysis method. Increases of temperature and reduction of hydrolysis times gave variable results. Although similar hydrolysis conditions were used in methods $\mathrm{E}$ and $\mathrm{F}$, the hydrolysis agent (MSA vs. $\mathrm{HCl}$ ) used was a significant factor in determination of milk AA. Indeed, milk amino acid concentrations determined by method $\mathrm{F}$ (using $\mathrm{HCl}$ ) were within the range reported for bovine milk by other authors (Davis et al., 1994). On the contrary, results obtained with method E (using MSA) were not similar to reported values in the literature. In addition, be- 
Table 2. Mean value of AA of cows' milk ( $\mathrm{mg} / \mathrm{g}$ of protein) determined by HPLC using different hydrolysis methods

\begin{tabular}{|c|c|c|c|c|c|c|c|c|}
\hline Amino acid & \multicolumn{7}{|c|}{ Method $^{1}$} & SEM \\
\hline Alanine & $40.47^{\mathrm{a}}$ & $41.90^{\mathrm{a}}$ & $40.85^{\mathrm{a}}$ & $40.45^{\mathrm{a}}$ & $40.06^{\mathrm{a}}$ & $34.87^{\mathrm{b}}$ & $32.62^{\mathrm{c}}$ & 0.62 \\
\hline Aspartic acid & $75.44^{\mathrm{d}}$ & $84.28^{\mathrm{b}}$ & $83.27^{\mathrm{b}}$ & $82.15^{\mathrm{c}}$ & $92.04^{\mathrm{a}}$ & $75.54^{\mathrm{d}}$ & $73.84^{\mathrm{d}}$ & 0.65 \\
\hline Cysteine & $7.53^{\mathrm{a}}$ & $3.14^{\mathrm{e}}$ & $5.44^{\mathrm{c}}$ & $4.85^{\mathrm{d}}$ & $5.21^{\mathrm{c}}$ & $6.30^{\mathrm{b}}$ & $7.66^{\mathrm{a}}$ & 0.15 \\
\hline Glutamic acid & $209.03^{\mathrm{e}}$ & $269.63^{\mathrm{a}}$ & $216.58^{\mathrm{d}}$ & $240.28^{\mathrm{c}}$ & $254.86^{\mathrm{b}}$ & $198.929^{f}$ & $211.68^{\mathrm{e}}$ & 1.20 \\
\hline Leucine & $98.70^{\mathrm{c}}$ & $109.53^{\mathrm{a}}$ & $104.16^{\mathrm{b}}$ & $95.33^{\mathrm{d}}$ & $95.61^{\mathrm{d}}$ & $95.02^{\mathrm{d}}$ & $98.20^{\mathrm{c}}$ & 0.82 \\
\hline Lysine & $86.71^{\mathrm{a}}$ & $66.31^{\mathrm{c}}$ & $56.32^{\mathrm{e}}$ & $85.58^{\mathrm{a}}$ & $63.51^{\mathrm{d}}$ & $76.65^{\mathrm{b}}$ & $85.25^{\mathrm{a}}$ & 0.65 \\
\hline Methionine & $24.67^{\mathrm{e}}$ & $32.28^{\mathrm{ab}}$ & $31.02^{\mathrm{b}}$ & $29.27^{\mathrm{c}}$ & $26.20^{\mathrm{d}}$ & $33.34^{\mathrm{a}}$ & $25.40^{\text {de }}$ & 0.58 \\
\hline Phenylalanine & $45.75^{\mathrm{d}}$ & $48.98^{\mathrm{c}}$ & $47.44^{\mathrm{cd}}$ & $42.23^{\mathrm{e}}$ & $53.80^{\mathrm{a}}$ & $51.34^{\mathrm{b}}$ & $46.31^{\mathrm{d}}$ & 0.75 \\
\hline Proline & $45.63^{\mathrm{f}}$ & $21.98^{\mathrm{g}}$ & $72.22^{\mathrm{c}}$ & $48.34^{\mathrm{e}}$ & $51.98^{\mathrm{d}}$ & $96.91^{\mathrm{a}}$ & $93.12^{\mathrm{b}}$ & 0.71 \\
\hline Serine & $61.34^{\mathrm{a}}$ & $60.31^{\mathrm{b}}$ & $62.88^{\mathrm{a}}$ & $60.90^{\mathrm{b}}$ & $51.78^{\mathrm{c}}$ & $49.36^{\mathrm{d}}$ & $53.12^{\mathrm{c}}$ & 0.65 \\
\hline Recovery (\%) & $87.09^{\mathrm{b}}$ & $75.08^{\mathrm{d}}$ & $78.32^{\mathrm{d}}$ & $83.61^{\mathrm{bc}}$ & $76.89^{\mathrm{d}}$ & $80.29^{\mathrm{cd}}$ & $95.52^{\mathrm{a}}$ & 1.55 \\
\hline
\end{tabular}

${ }^{\mathrm{a}-\mathrm{g}}$ Means within a row with different superscripts differ $(P<0.05)$.

${ }^{1}$ Ref. $=$ reference method (AOAC, 1994); conditions for other methods are shown in Table 1.

cause MSA is not volatile, it cannot be evaporated after hydrolysis; hence, greater sample amounts have to be used for hydrolysis. Conversely, $\mathrm{HCl}$ can be evaporated after hydrolysis, so the hydrolysate is recovered in a small volume (Weiss et al., 1998). To test the accuracy of the proposed methods, analytical recovery was evaluated. As can be observed in Table 2, recovery of total milk AA was $95.52 \%$ for method $\mathrm{F}$ compared with
$87.10 \%$ for the reference method; the other methods showed lower recovery percentages ranging from 75.08 to $83.61 \%$. Table 3 shows recovery percentages of each amino acid for the tested hydrolysis methods. Method F was characterized by higher accuracy than the reference method for alanine $(P<0.01)$, arginine, glycine, histidine, proline, serine, and threonine $(P<0.001)$, whereas no significant differences were found for the

Table 3. Mean value of recovery percentages of different hydrolysis methods

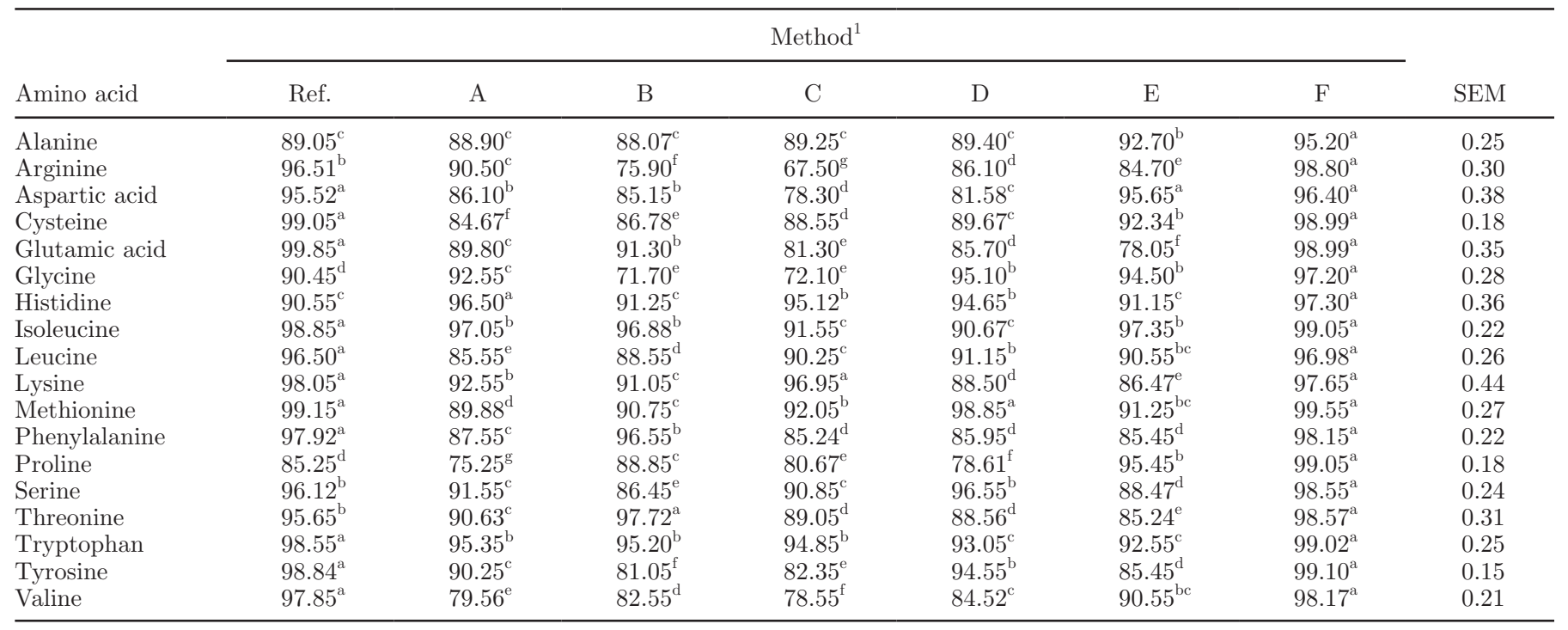

${ }^{\mathrm{a}-\mathrm{g}}$ Means within a row with different superscripts differ $(P<0.05)$.

${ }^{1}$ Ref $=$ reference method (AOAC, 1994); conditions for other methods are shown in Table 1. 
Table 4. Linearity parameters, limits of detection and quantification (LOD and LOQ), and performance parameters of the analytical method proposed (method F)

\begin{tabular}{|c|c|c|c|c|c|}
\hline Amino acid & $\mathrm{r}^{2}$ & LOD & LOQ & $\mathrm{CV}(\%)$ & $\begin{array}{c}\text { Repeatability } \\
\text { uncertainty (\%) }\end{array}$ \\
\hline Alanine & 0.998 & 0.75 & 2.28 & 3.8 & 1.5 \\
\hline Arginine & 0.998 & 1.37 & 4.15 & 1.7 & 0.7 \\
\hline Aspartic acid & 0.996 & 1.27 & 3.87 & 1.9 & 0.8 \\
\hline Cysteine & 0.996 & 1.78 & 5.4 & 4.6 & 1.8 \\
\hline Glutamic acid & 0.996 & 1.53 & 4.63 & 0.7 & 2.8 \\
\hline Glycine & 0.997 & 0.97 & 2.95 & 1.4 & 0.6 \\
\hline Histidine & 0.997 & 1.45 & 4.39 & 1.1 & 0.5 \\
\hline Isoleucine & 0.997 & 1.21 & 3.66 & 2.3 & 0.9 \\
\hline Leucine & 0.997 & 1.2 & 3.62 & 0.6 & 0.2 \\
\hline Lysine & 0.99 & 2.59 & 7.71 & 4.3 & 1.7 \\
\hline Methionine & 0.997 & 1.4 & 4.25 & 2.9 & 1.2 \\
\hline Phenylalanine & 0.998 & 1.3 & 3.93 & 1.6 & 0.6 \\
\hline Proline & 0.991 & 1.74 & 5.26 & 4 & 1.6 \\
\hline Serine & 0.998 & 0.76 & 2.31 & 0.8 & 0.3 \\
\hline Threonine & 0.997 & 1.1 & 3.32 & 1.7 & 0.6 \\
\hline Tryptophan & 0.998 & 1.52 & 3.59 & 2.5 & 1 \\
\hline Tyrosine & 0.998 & 1.6 & 4.86 & 0.9 & 0.3 \\
\hline Valine & 0.998 & 0.91 & 2.76 & 0.7 & 0.3 \\
\hline
\end{tabular}

other AA. It is worth noting that the mean recovery value of the single AA detected with method $\mathrm{F}$ was $98.38 \%$, ranging between 97.20 and $99.84 \%$, except for alanine (95.20\%).The linearity parameters expressed as determination coefficients and the relative LOD and LOQ of each amino acid detected after hydrolysis with method $\mathrm{F}$ are reported in Table 4. All the AA showed good linearity with coefficients of determination $\left(\mathrm{r}^{2}\right)$ $>0.99$. The highest LOD and LOQ were recorded for lysine, whereas the lowest values were recorded for alanine and serine. The coefficients of variation related to the AA concentrations registered were $<4.6 \%$, with a mean value of $2.1 \%$; this could be considered an index of high repeatability, according to the European Commission (2002).

To summarize, hydrolysis of milk samples using 6 $N \mathrm{HCl}$ at $160^{\circ} \mathrm{C}$ for 60 min (method F) permits good quantification of milk AA associated with increased accuracy together with the possibility to analyze an increased number of milk samples in short time. The proposed modification for derivatization procedure allowed us to obtain good chromatographic resolution and excellent asymmetry of the peaks. Therefore, method $\mathrm{F}$ was characterized by high precision and low repeatability uncertainty for all AA evaluated.

\section{REFERENCES}

AOAC. 1994. Official Methods of Analysis. 16th ed. Association of Official Analytical Chemists, Arlington, VA.

Davis, T. A., H. V. Nguyen, R. Garcia-Bravo, M. L. Fioretto, E. M. Jackson, D. S. Lewis, D. R. Lee, and P. J. Reeds. 1994. Amino acid composition of human milk not unique. J. Nutr. 124:1126-1132.

European Commission. 2002. Decision 2002/657/EC of 12 August 2002 implementing Council Directive 96/23/EC concerning the performance of analytical methods and the interpretation of results. Off. J. L22:8-36.

Fountoulakis, M., and H. W. Lahm. 1998. Hydrolysis and amino acid composition analysis of proteins. J. Chromatogr. A 826:109134.

Henderson J. W., R. D. Ricker, B. A. Bidlingmeyer, and C. Woodward. 2000. Rapid, accurate, sensitive, and reproducible HPLC analysis of amino acids. Agilent Technologies, assignee. US Pat. No. 5980$1193 \mathrm{E}$.

Hund, E., D. L. Massart, and J. Smeyers-Verbeke. 2001. Operational definitions of uncertainty. Trends Anal. Chem. 20:394-406.

IDF. 1990. Determination of milk fat, protein and lactose contentGuide for the operation of mid-infra-red instruments. IDF Standard No. 141B. International Dairy Federation, Brussels, Belgium.

Miller, J. C., and J. N. Miller. 1993. Regression and correlations. Pages 115-117 in Statistics for Analytical Chemistry. 3rd ed. Ellis Horwood PTR Prentice-Hall, New York, NY.

Tristam, G. R. 1953. The amino acid composition of proteins. Pages 181-233 in The Proteins. Vol. 1. H. Neurath and K. Bailey, ed. Academic Press, New York, NY.

Weiss, M., M. Manneberg, J. F. Juranville, H. W. Lahm, and M. Fountoulakis. 1998. Effect of the hydrolysis method on the determination of the amino acid composition of proteins . J. Chromatogr. A 795:263-275. 